\title{
PENINGKATAN DAYA SAING HOME INDUSTRY DODOL DI KELURAHAN HUTASUHUT KECAMATAN SIPIROK KABUPATEN TAPANULI SELATAN
}

\author{
Indra Muda $^{1^{*}}$, Rosmala Dewi ${ }^{1}$, Hery Syahrial $^{1}$ \\ ${ }^{1}$ Jurusan Administrasi Publik, Fakultas Ilmu Sosial dan Ilmu Politik, Universitas Medan Area, Medan, Indonesia \\ * Penulis Korespodensi : indramudahts@gmail.com
}

\begin{abstract}
Abstrak
Industri rumah tangga merupakan salah satu aspek penguatan ekonomi. Daya serapnya yang luas dapat memberdayakan ekonomi rakyat. Keberadaannya perlu ditingkatkan agar dapat membantu pemerintah membuka lapangan pekerjaan baru. Untuk membantu pemerintah menanggulangi masalah tersebut, Fakultas Ilmu Sosial dan Ilmu Politik Universitas Medan Area terpanggil turut menanggulanginya yang berfokus kepada pemberdayaan industri rumah tangga melalui pengabdian kepada masyarakat. Kegiatan ini melibatkan masyarakat setempat, aparat dari Disperindag untuk memberikan penyuluhan dan sosialisasi kepada pengusaha dodol sipirok tentang cara membuat kemasan yang baik, cara meningkatkan daya saing produksi. Kegiatan ini dilaksanakan pada industri rumah tangga dodol milik Fahruddin Ritonga dan Samsul Siagian selama 8 bulan. Berdasarkan hasil pengabdian, perubahan kemasan dari sumpit menjadi kotak, menambah kepercayaan konsumen terhadap hygienitas dodol. Dengan perubahan kemasan ke dalam bentuk kotak berpengaruh positif terhadap peningkatan permintaan konsumen. Untuk memenuhi peningkatan permintaan konsumen, pengusaha melakukan penambahan tenaga kerja untuk memproduksi dodol. Penyuluhan yang disampaikan petugas dari Dinas Perindustrian dan Perdagangan Kabupaten Tapanuli Selatan ke tempat usaha dodol rizki dan dodol rahmat sangat bermanfaat untuk menciptakan produk yang sesuai dengan standard kesehatan.
\end{abstract}

Kata kunci: PKM Industri Rumah Tangga, Dodol Sipirok, Tapanuli Selatan.

\begin{abstract}
Home industry is one aspect of strengthening the economy. Its extensive absorption can empower the people's economy. Its existence needs to be improved so that it can help the government open new jobs. To help the government overcome this problem, the Faculty of Social and Political Sciences of the University of Medan was called to participate in overcoming it, which focused on empowering home industries through community service. This activity involved the local community, officials from the Disperindag to provide information and socialization to dodol sipirok entrepreneurs on how to make good packaging, how to improve production competitiveness. This activity was carried out in the dodol home industry owned by Fahruddin Ritonga and Samsul Siagian for 8 months. Based on the results of service, changes in packaging from chopsticks to boxes, adding to consumer confidence in the hygiene hygiene. With changes in packaging in the form of boxes has a positive effect on increasing consumer demand. To meet the increase in consumer demand, employers are adding jobs to produce dodol. Counseling delivered by officers from the Department of Industry and Trade of South Tapanuli Regency to the dodol rizki business place and dodol rahmat is very useful to create products that comply with health standards.
\end{abstract}

Keywords: Home Industry PKM, Dodol Sipirok, South Tapanuli.

\section{PENDAHULUAN}

Dodol Sipirok merupakan salah satu makanan khas yang berasal dari Kecamatan Sipirok Tapanuli Selatan, pada awalnya diproduksi secara musiman. Pada dasarnya dodol dibedakan menjadi dua macam yaitu, berdasarkan buah yang ditambahkan dan berdasarkan tempat pengolahannya. Jenis dodol berdasarkan buah misalnya dodol nanas, dodol durian sedangkan berdasarkan tempat pengolahan seperti, dodol Garut, dodol Sabang, dodol Sipirok. (Marajer dkk, 2015).

Dengan demikian, dodol sipirok merupakan jenis dodol berdasarkan tempat, yang bercirikan nama yang memproduksinya. Makanan cemilan dodol Sipirok biasanya muncul menjelang lebaran (Idul Fitri). Tujuannya adalah untuk disajikan kepada tamu yang datang berlebaran ke rumah-rumah warga. Karena 
sudah menjadi kebiasaan turun-temuruan, pada Hari Raya Idul Fitri banyak perantau yang pulang kampung. Usai lebaran, saat mereka kembali ke tempat asalnya, buah tangan atau oleh-oleh yang diberikan warga setempat kepada para tamu yang datang tersebut adalah dodol yang dikemas dalam wadah yang terbuat dari anyaman daun pandan, yang biasa disebut sumpit.

Proses produksi dodol sipirok masih menggunakan cara tradisional dengan mengandalkan tenaga manusia. Proses produksi dengan menggunakan tenaga manusia dimulai dari proses pengadonan, mengaduk dodol dalam belanga besar hingga proses pengemasan. Komposisi bahan untuk memproduksi dodol terdiri dari gula aren, sari santan kelapa, tepung ketan, yang dididihkan hingga akan menjadi padat, kenyal dan dapat diiris. (Haryadi, 2006). Bahan-bahan tersebut dipilih dari kualitas terbaik, supaya dapat menghasilkan cita rasa menarik hingga banyak konsumen yang menyukai. Aroma tidak hanya ditentukan oleh satu komponen tetapi oleh beberapa komponen tertentu yang menimbulkan bau yang khas serta perbandingan berbagai komponen bahan. Bau makanan banyak menentukan kelezatan bahan makanan tersebut. (Budianto dkk, 2012).

Selain dari pada aroma dodol sipirok yang harum dan khas, juga memiliki kandungan gizi tinggi sehingga cocok sebagai bahan cemilan yang mengenyangkan. Pati dari tepung beras ketan memiliki kandungan amilopektin yang tinggi hal ini mempengaruhi sifat elastisitas.

Proses memasak dodol sipirok dilakukan dengan menempatkan seluruh bahan adonan dalam kuali besar diatas bara api dengan menggunakan kayu bakar sebagai bahan bakar utama. Dengan demikian, dodol sipirok digolongkan pangan semi basah yang berstektur kenyal, memiliki cita rasa manis sehingga dapat langsung dimakan. (Inhito dkk, 2017). Untuk menghasilkan produk dodol sipirok yang demikian, harga jualnya Rp.10.000 s/d Rp.25.000/sumpit sehingga tidak semua calon konsumen dapat menjangkau harga tersebut.

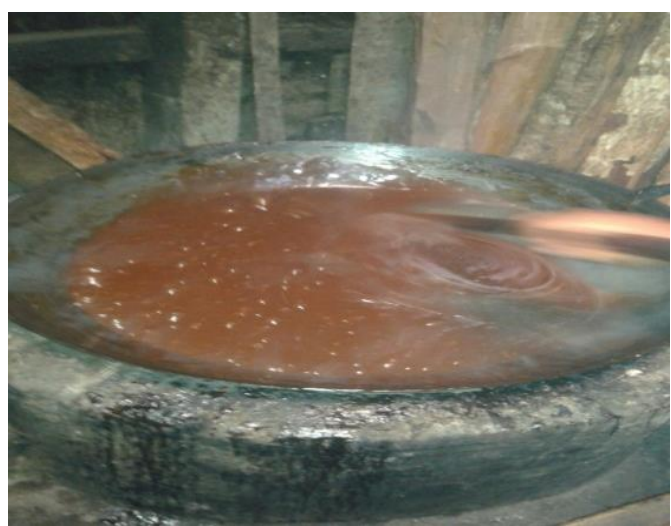

Gambar 1. Proses mengaduk dodol.

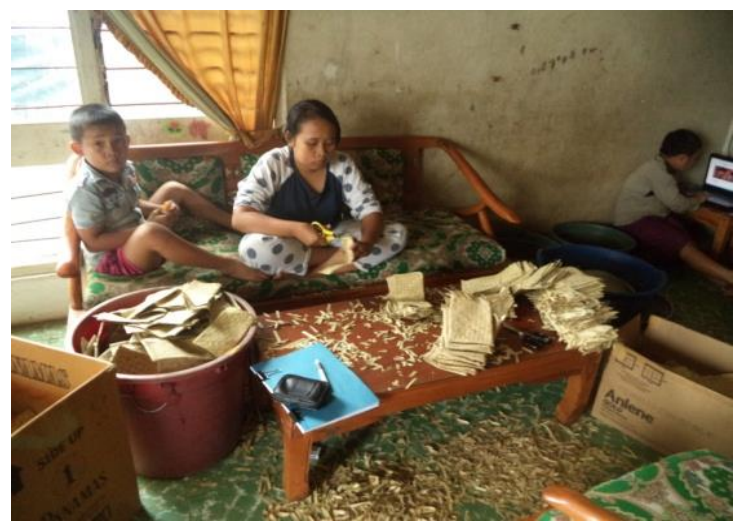

Gambar 2. Proses pengemasan dodol.

Permasalahan mitra (1) Fahruddin Ritonga, sudah melakoni pekerjaan memproduksi dodol sipirok selama lebih kurang 10 tahun yang dijalankan secara tradisional dalam arti, proses produksi dikerjakan sendiri oleh keluarganya yang dibantu oleh beberapa orang penduduk setempat. Dengan proses produksi menggunakan tenaga manusia tanpa standar yang baku, menyebabkan kualitas produksi setiap kali produksi tidak sama rasanya, termasuk dalam proses pengadonan masih menggunakan taksiran atau perkiraan. Persoalan lain yang dihadapi mitra adalah cara pemasaran. Usaha rumah tangga ini masih tervokus kepada pesanan pembeli. Jadi apabila tidak ada pesanan, kadang kala kegiatan produksi dihentikan atau paling tidak diproduksi dalam jumlah kecil. Produksinya akan meningkat terutama menjelang lebaran (idul fitri) atau menjelang musim panen padi di Kecamatan Sipirok sekitarnya karena masyarakat perantau biasanya banyak yang pulang kampung untuk mengambil hasil pertaniannya.

Permasalahan mitra (2), Samsul Siagian sama dengan mitra (1). Produk yang dihasilkan, dititip pada kios-kios atau toko-toko yang menjual makanan khas sipirok di Pasar Sipirok bahkan pada beberapa pasar di luar sipirok seperti, Padang Sidempuan, Palsabolas sehingga konsumennya tidak hanya warga lokal melainkan warga yang singgah di sipirok dengan kenderaan umum dan mobil pribadi. Sistem pembayaran dodol yang dititip pada kios dan toko dilakukan setelah produk terjual. Apabila dodol dalam wadah sumpit terlalu lama dititip di warung-warung atau di toko, daya tariknya akan berkurang karena terkena debu, bahkan sampai berjamur sehingga harus ditarik dari peredaran yang tentu saja akan menimbulkan kerugian bagi produsen dodol sipirok.

\section{METODE PELAKSANAAN}

Sehubungan dengan permasalahan mitra, maka metode pelaksanaan pengabdian yang dilakukan adalah, meminta kesediaan mitra merubah cara produksi dengan memakai sarana dan fasilitas produksi yang bersih hygienis. Kemudian, mitra dibimbing untuk membuat kemasan yang variatif (kemasan besar, sedang dan kecil). Oleh karena itu kemasan dirubah dari bentuk sumpit menjadi kotak-kotak kemudian pada setiap kotak mencantumkan label. Untuk meningkatkan omzet 
penjualan mitra, tim pengabdi menghubungi pedagang pengecer, grosir dan swalayan di Kota Padang Sidempuan, Balige, Sibolga. Untuk langkah perluasan selanjutnya tim merencanakan untuk memperluas pemasaran ke Provinsi Sumatera Barat dan Kota Medan.

\section{HASIL DAN PEMBAHASAN}

Industri merupakan kegiatan yang komplek yang mencakup berbagai faktor yang saling berkaitan dan berhubungan satu sama lain yang merupakan totalitas, yang juga dianggap penting jika ditinjau dari segi skala usaha. Hal ini sangat berguna untuk menggambarkan ukuran setiap pabrik dan perusahaan yang berbentuk industri.

Skala dari setiap pabrik biasanya ditentukan oleh tehnologi dan sifat produksi yang dihasilkan. Namun bagi suatu negara, besar kecilnya mungkin berbeda-beda dengan industri negara lain. Karena suatu industri di Indonesia dianggap besar, tetapi di negara lain mungkin beranggapan sebaliknya. Sebagai skala dipakai pula berbagai ukuran seperti investasi, jumlah tenaga kerja, output dan sebagainya.

Industri kecil ialah industri-industri yang mempergunakan jumlah buruh tidak lebih dari sepuluh orang dan memakai tenaga mesin tidak lebih dari lima kekuatan kuda atau industri-industri yang mempergunakan jumlah buruh tidak lebih dari dua puluh orang dengan tidak mempergunakan tenaga mesin atau lain-lain daya gerak yang sama dengan tenaga mesin. (Soenartadirdja, 2010).

Pembangunan industri dengan tingkat teknologi modern, dengan sendirinya akan membawa pengaruh pada masyarakat sekitar. Bagi Industri rumah tangga, tentunya dengan diperkenalkannya keterampilan industri baru akan dapat mengubah cara-cara kerja tradisional yang telah berlangsung lama. Produktifitas yang meningkat perlu pula diimbangi dengan usaha perluasan pemasaran dari produk masyarakat itu. Oleh karenanya, cara-cara kerja modern juga perlu diperkenalkan sehingga dapat menimbulkan eksesekses sosial ekonomi yang positif yang dapat meningkatkan kesejahteraan pengusaha dan menguntungkan Pembangunan Daerah. Demikian juga penerapan tehnologi baru pada masyarakat perlu diimbangi dengan usaha-usaha pengembangan, seperti penyuluhan, pendampingan, pendidikan kader, pameran-pameran, dan sebagainya. Disamping itu pemerintah perlu memecahkan masalahmasalah yang timbul akibat modernitas tersebut yaitu berupa penelitian masalah kualitas produk, masalah pemasaran, masalah organisasi dan lain-lain. Hal yang tidak dapat dipungkiri bahwa, dengan adanya industri di suatu daerah biasanya akan meningkatkan pendapatan masyarakat di daerah tersebut, sehingga membuka kesempatan kerja yang mampu merubah pola hidup konsumtif menjadi pola hidup produktif.
Sektor industri kecil merupakan kegiatan yang dapat mempercepat tercapainya modernitas dengan memperkenalkan cara kerja baru, peralatan yang modern, prosedur kerja, organisasi dan sebagainya. Dengan berobahnya pola sosial masyarakat akan menjadi titik tolak bagi pemupukan jiwa entrepreneurship yang sangat diperlukan dalam dunia modern. Dalam hal ini, kedudukan industri kecil dan rumah tangga dalam pembangunan nasional adalah sangat vital, baik sebagai sarana untuk memperluas kesempatan kerja, sebagai penggerak perekonomian daerah maupun sebagai katalisator dalam usaha modernitas daerah. Namun demikian pembangunan industri pada khususnya dan pembangunan daerah pada umumnya tidak dapat berdiri sendiri, ia memerlukan sikap mental yang baik, dan harus dapat bekerja sama antara pemerintah daerah dengan daerah-daerah sekelilingnya. Demikian juga perlu adanya kerja sama antara pemerintah daerah dengan para pengusaha dan pengrajin di daerahnya, sehingga setiap persoalan yang timbul sebagai akibat pembangunan dapat dipecahkan bersama secara efisien dan efektif.

Pembangunan regional memiliki posisi yang central untuk mendukung keberhasilan pembangunan Nasional, yaitu untuk mewujudkan masyarakat adil dan makmur yang merata materil/spiritual. Oleh karenanya, baik pemerintah pusat maupun daerah senantiasa perlu menggali berbagai potensi yang tersedia pada masingmasing daerah. Salah satu upaya untuk meningkatkan potensi ekonomi di daerah adalah menghidupkan sektor industri termasuk industri rumah tangga. Industri telah diakui sebagai sektor penunjang utama pembangunan regional. Kegiatan ini memang beralasan, mengingat banyaknya daerah yang ditunjang oleh industri, ternyata memperlihatkan hasil yang cukup menggembirakan (Mardi, (2012).

Pembangunan Daerah dapat dikatakan berhasil apabila di daerah itu bisa diciptakan kesempatan kerja yang luas dan merata. Pembangunan pabrik-pabrik di suatu daerah dengan sendirinya akan membuka lapangan pekerjaan baru, "Jadi masalah ketenagakerjaan harus dipecahkan dengan melihat aspek-aspek lainnya. Diantaranya adalah perluasan sektor-sektor padat karya, seperti industri kecil, sektor jasa, industri rumah tangga, kerajinan rakyat dan sebagainya ". (Sukadji, 2010)

Dapat dikatakan, pembangunan sektor industri dan usaha rumah tangga memerlukan penggalian berbagai usaha dan daya yang ada melalui sumber-sumber yang tersedia, sesuai dengan potensi daerah masing-masing Industri telah diakui sebagai sektor penunjang utama pembangunan regional. Kegiatan ini memang sangat beralasan, karena mengingat banyaknya daerah yang ditunjang oleh sektor industri, dan ternyata memperlihatkan hasil yang cukup menggembirakan (Mardi, 2012). 
Hal ini menunjukkan, sektor industri kecil dan kerajinan memegang peranan penting memperluas kesempatan kerja, karena industri kecil tidak memerlukan keahlian yang tinggi, tidak memerlukan mesin-mesin dan modal yang besar. Namun demikian karena industri kecil umumnya masih dikelola secara tradisional dimana horizon pemasarannya masih bersifat lokal dan untuk meningkatkan efisiensi dan mampu bersaing, maka industri kecil tersebut perlu dibina dan dibimbing guna menuju modernitas.

Industri rumah tangga dodol Rizki dan dodol Rahmat dimulai tanpa perencanaan matang, bersifat coba-coba. Dibangun karena kebutuhan ekonomi keluarga dan usaha yang diwariskan dari orang tua. Meski pada awalnya sang pemilik tidak tertarik dengan bisnis ini, berhubung tidak ada pekerjaan lain maka usaha yang telah dirintis orang tua selama bertahun-tahun lamanya terus dikembangkan. Oleh karenanya, proses produksi dodol dan cara pemasaran adalah pola yang telah dikembangkan sebelumnya berdasarkan pengalaman keluarga.

Berdasarkan wawancara yang tim lakukan dengan pemilik industri rumah tangga dodol Rizki bahwa, "kegiatan usaha ini dilakukan karena tidak memiliki pekerjaan lain kecuali bertani. Jadi untuk mencari tambahan penghasilan dengan kebutuhan keluarga yang semakin berat, maka keluarga bersepakat untuk mengelola usaha dodol". Pernyataan yang sama disampaikan bapak Samsul Siagian, pemilik industri rumah tangga dodol Rahmat, "setelah pulang merantau dari Makassar saya memiliki pemikiran untuk membangun usaha dodol dengan modal terbatas. Atas desakan ekonomi yang semakin berat, maka usaha ini dikembangkan dalam berbagai keterbatasan finansial".

Keterbatasan wawasan bapak Fahruddin Ritonga dan Samsul Siagian dalam mengelola kegiatan usahanya, menyebabkan perkembangan usaha berjalan stagnan, jalan di tempat dan tidak memiliki masa depan yang baik. Namun, permintaan pasar yang terus meningkat dan budaya memakan dodol/alame di Kecamatan Sipirok yang terus berkembang sebagai kuliner unggulan lokal menyebabkan semangat untuk mengembangkan usaha semakin bergelora.

Melihat fenomena ini, hal pertama yang tim pengabdi tawarkan kepada mitra dalam rangka menyempurnakan produksi dodol adalah melakukan perbaikan proses produksi. Untuk melakukan perbaikan dan penyempurnaan proses produksi, tim pengabdi mengundang petugas dari Dinas Perindustrian dan Perdagangan Kabupaten Tapanuli Selatan dalam rangka memberikan penyuluhan kepada pemilik industri dodol Rizki dan Dodol Rahmat. Pada kesempatan ini, petugas tersebut memberikan contoh kepada pemilik industri dodol Rizki dan dodol Rahmat agar menggunakan air yang bersih untuk dalam memproduksi dodol, demikian juga dengan santan kelapa dan tepung ketan yang dipergunakan agar diperhatikan hygienitasnya. Untuk itu, setiap bahan-bahan yang diperlukan agar ditempatkan pada tempat tertentu yang tidak bisa tersentuh tikus, lipas atau binatang-binatang beracun lainnya.

Terkait dengan kemasan, tim pengabdi menawarkan untuk membuatnya dalam bentuk yang menarik. Kemasan produk atau packaging produk sangatlah berkaitan erat dengan branding. Kemasan pada produk merupakan salah satu unsur yang mempengaruhi banyaknya penjualan atau minatnya konsumen terhadap produk tersebut. Oleh karenanya, produsen harus memikirkan untuk membuat kemasan yang terbaik untuk produknya.

Banyak pengusaha yang memiliki pandangan bahwa kualitas sebuah produk dan cara pemasaran jauh lebih diutamakan untuk meningkatkan penjualan, dibandingkan fokus pada kemasan produk. Padahal beberapa unsur yang mempengaruhi penjualan produk seperti kualitas produk, pelayanan, pemasaran, dan kemasan juga saling mendukung satu sama lain. Jadi, belum tentu jika produk dengan kualitas yang bagus akan banyak peminatnya, kecuali bila konsumen tersebut benar-benar membutuhkannya. Kemasan produk inilah yang mungkin perlu pikirkan sebagai bagian dari strategi pemasaran.

Berdasarkan pengamatan yang tim pengabdi lakukan terhadap bentuk kemasan dodol Rizki dan dodol Rahmat, terbuat dari sumpit yang berbahan dasar dari daun pandan, jelas kurang memiliki daya tarik bagi konsumen untuk membelinya. Demikian juga dengan hygienitasnya yang merupakan hasil kerajinan para ibuibu dianyam secara tradisional. Dengan bentuk kemasan ini, tim pengabdi berdiskusi dengan mitra agar kemasan dapat dirubah menjadi lebih menarik dan memiliki daya tarik bagi konsumen.

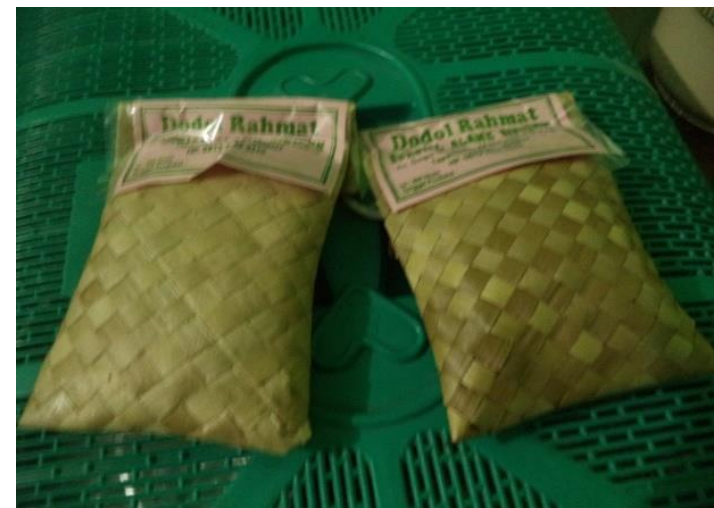

Gambar 3. Kemasan lama produk dodol rizki dan dodol rahmat.

Gambar diatas adalah bentuk kemasan lama dodol rizki dan dodol rahmat. Bahan kemasan terbuat dari sumpit berbahan dasar daun pandan (dalam bahasa mandailing disebut bayon). Tanaman ini biasanya tumbuh pada lahan rawa. Setelah dikeringkan sekitar 3 hari pada terik matahari baru dapat dianyam oleh para pengrajin. Namun hygienitas atau kebersihannya tetap saja kurang terjaga karena dijemur pada ruang terbuka. 
Melalui diskusi yang dilakukan tim pengabdi dengan mitra, disepakati bahwa kemasan bersedia mereka ganti dengan motif seperti di bawah ini.

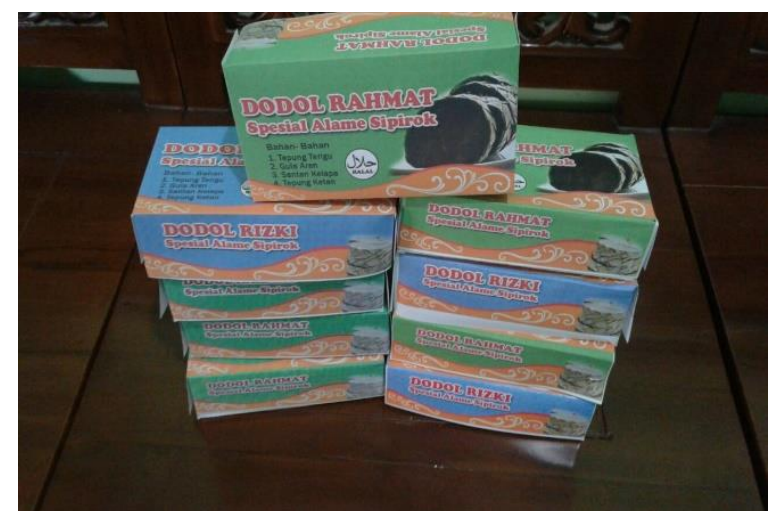

Gambar 4. Kemasan baru dodol rizki dan dodol rahmat.

Gambar diatas menunjuukan model kemasan baru dodol rizki dan dodol rahmat. Dalam kemasan dicantumkan bahan-bahan yang digunakan untuk pembuatan dodol, sedangkan untuk ijin Deperindag belum dicantumkan karena masih dalam tahap pengurusan. Demikian juga dengan MUI Tapanuli Selatan masih diupayakan kelengkapan persyaratan yang diperlukan untuk hal tersebut, sedangkan ijin dari Departemen Kesehatan sudah dicantumkan.

Sekitar 2 (dua) bulan setelah kemasan ini diperkenalkan kepada konsumen, permintaan terus meningkat $75 \%$. Pengusaha tetap memproduksi kemasan lama dalam sumpit. Harga jual dodol untuk kemasan lama ditetapkan Rp.10.000 per sumpit dengan berat 2,5 ons, sedangkan untuk kemasan baru dengan kemasan kotak ditambah kemasan aluminium foil ditetapkan besaran harga Rp.13.000 per kotak. Jadi, untuk memenuhi permintaan pasar, industri rumah tangga dodol rizki dan dodol rahmat hingga tahun 2018 memproduksi dodol dalam dua bentuk kemasan yaitu dalam bentuk sumpit dan dalam bentuk kotak.

Kemasan aluminium foil tersebut, dapat dilihat seperti gambar di bawah ini.

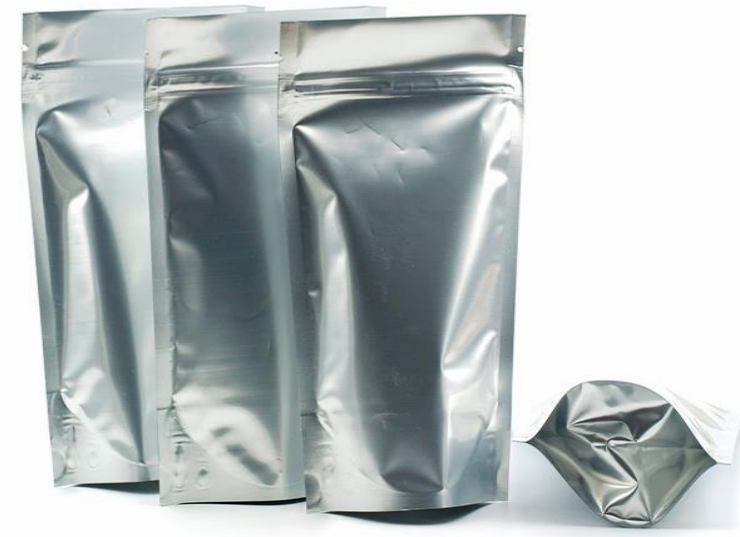

Gambar 5. Kemasan dodol rizki dan dodol rahmat dalam aluminium foil.
Dengan penggunaan bahan aluminium foil dalam kemasan dodol rizki dan dodol rahmat yang baru, dodol terlebih dahulu dimasukkan ke dalam aluminium foil, kemudian baru dimasukkan ke dalam kotak kemasan. Dengan cara pengemasan dodol yang demikian, hygienitasnya lebih terjamin demikian juga dengan aromanya tetap dapat harum dan wangi meski sudah dua minggu tanpa bahan pengawet. Rasanyapun tidak mengalami perubahan.

Penyempurnaan proses produksi dan perbaikan kemasan dodol rizki dan dodol rahmat membawa pengaruh positif terhadap peningkatan permintaan konsumen. Untuk memenuhi peningkatan permintaan konsumen dilakukan penambahan tenaga kerja dan perluasan pasar. Untuk memperluas pemasaran, maka dilakukan riset pasar untuk mengetahui apa yang diinginkan pasar serta berapa jumlahnya. Dalam hal ini hanya industri rumah tangga dodol rahmat yang memiliki keberanian untuk memperluas pangsa pasar hingga ke Balige, Padangsidempuan dan Tarutung, sedangkan pemilik dodol rizki lebih vokus kepada pasar lokal dengan memperluas tempat-tempat penitipan produk pada toko dan tempat penjualan kuliner di pasar Sipirok.

Dengan meningkatkan jumlah produk pada pelanggan yang sudah ada juga dapat menambah asset penjualan, hal ini di dukung dengan semakin strategisnya lokasi pasar Sipirok sebagai translintas sumatera yang banyak dilalui mobil pribadi, bus Angkutan Kota Antar Provinsi dan Angkutan Kota Dalam Provinsi.

Pada pasar lokal, dodol sipirok merupakan salah satu kuliner yang dicari konsumen, selain rasanya yang gurih juga menjadi makanan khas dari daerah ini sehingga keberadaannya semakin penting. Berbagai jenis keripik dan kue-kue tradisional juga banyak tersedia di pusatpusat kuliner, sehingga selain menjadi oleh-oleh atau buah tangan juga sering dimanfaatkan pengunjung sebagai makanan cemilan dalam perjalanan.

Semakin dinamisnya prilaku konsumen dalam bisnis menyebabkan produsen dodol perlu tanggap akan berbagai permintaan tersebut. Kini sudah berkembang kepada bisnis online. Menurut wawancara yang tim pengabdu lakukan dengan bapak Samsul Siagian mengemukakan, "permintaan konsumen terhadap dodol Rahmat kini sudah memasuki era online misalnya dari Batam bahkan ada yang dari Papua. Sudah pernah melakukan pengiriman melalui JNE, namun ongkosnya terlalu mahal. Tapi bagi monsumen ongkos kirim tidak menjadi masalah, yang penting bagi mereka adalah dapat menikmati cita rasa dodol sipirok".

Seriring dengan perkembangan bisnis dan permintaan konsumen yang kian dinamis, maka pemilik industri rumah tangga dodol Rahmat terus melakukan penyempurnaan kegiatan usahanya, meski belum seluruhnya dapat dibenahi. Dalam pengembangan bisnis lanjutan, benturan yang paling dirasakan adalah keterbatasan modal. Untuk mendapatkan modal kerja, 
usaha dodol Rahmat melakukan pengajuan kredit kepada pihak Bank dengan cara perhitungan yang hatihati.

\section{SIMPULAN}

1) Perubahan kemasan dodol rizki dan dodol rahmat dari bentuk sumpit ke bentuk kotak menambah daya tarik konsumen untuk membelinya. Dengan perubahan kemasan ini penjualan meningkat hingga $75 \%$. Peningkatan omzet penjualan bahkan mencapai $150 \%$ pada moment lebaran idul fitri.

2) Untuk memenuhi permintaan konsumen yang semakin besar, pengusaha dodol rizki dan dodol rahmat melakukan penambahan tenaga kerja, terutama tenaga untuk mengaduk dodol pada saat proses pemasakan. Dengan penambahan tenaga kerja tersebut, dapat membuka lapangan pekerjaan baru bagi masyarakat sekitar.

3) Peningkatan jumlah produksi sebagai dampak dari penambahan tenaga kerja secara rutin, maka dilakukan perluasan pasar external ke Balige, Palsabolas, Padangsidempuan dan dilakukan pemasaran secara online. Untuk kegiatan pemasaran ini, tim pengabdi membantu pengusaha dalam memberikan bimbingan dan menjajaki pedangan yang menampung produk di daerah tersebut.

\section{SARAN}

1) Untuk memasukkan produk ke super market, pengusaha dodol rizki dan dodol rahmat agar mengurus ijin usaha, ijin Majelis Ulama Indonesia Kabupaten Tapanuli Selatan.

2) Untuk meningkatkan wawasan dan kreasi produk, pengusaha supaya lebih aktif mengikuti pelatihan, seminar termasuk mengikuti pameran-pameran industry, sehingga mendapat inovasi baru.

3) Studi banding kepada perusahaan yang memproduksi barang yang sejenis termasuk di luar daerah perlu untuk meningkatkan pengetahuan pemilik industri.

4) Sistem kemitraan dengan swalayan, toko grosir dan pedagang kuliner supaya diperluas setelah memenuhi syarat-syarat legalitas produk yang diperlukan.

\section{DAFTAR PUSTAKA}

Marajer, B., Pato, U., \& Fortuna, D. (2017). Karakteristik Mutu Dodol Ketan Dengan Penambahan Pisang Ambon dan Jambu Biji, Jurnal Faperta Vol. 4. No. 2: Oktober 2017.

Budianto., Harun, N., \& Efendi, R. (2015). Evaluasi Mutu Dodol Berbasis Tepung Ketan dan Buah Pedada, Jurnal Faperta, Vol 2. No. 2: Oktober 2015.

Haryadi. (2006). Teknologi Pengolahan Beras, Gajah Mada University Press, Yogjakarta.

Mardi, K. (2012), Pembangunan Perindustrian di Indonesia, Erlangga, Jakarta.

Inhito, M. S., Siyarto., \& Jayus. (2017). Sifat Fisik, Kimia dan Orgamoleptik Dodol Hasil Variasi Rasio Tomat dan Tepung rumput Laut, Jurnal Agroteknologi, Vol. 2 No. 1: 2017.
Sukadji. (2010). Industri dalam Perkembangannya. Balai Pustaka: Jakarta.

Soenartadirdja. (2010). Industri Kecil dan Pembangunan Ekonomi, Balai Pustaka:Jakarta. 